\title{
Pengaruh Current Ratio, Net Profit Margin, Stabilitas Penjualan dan Struktur Aktiva terhadap Struktur Modal di BEI Periode 2014- 2017
}

\author{
Jessica Tanri \\ Universitas Prima Indonesia \\ jessicatanri98@gmail.com \\ Liviaty Vandana \\ Universitas Prima Indonesia \\ liviatyvandana@gmail.com
}

\author{
Francroyce Zulion Behrry \\ Universitas Prima Indonesia \\ francroyce.z.b@gmail.com \\ Ira Martika Winarno \\ Universitas Prima Indonesia \\ iramartikaa.tik@gmail.com
}

\author{
Adam Afiezan \\ Universitas Prima Indonesia \\ Adamafiezan@unprimdn.ac.id
}

\begin{abstract}
ABSTRAK
Tujuan penelitian ini adalah untuk mengetahui pengaruh Current Ratio,Net Profit Margin,Stabilitas Penjualan dan Struktur Aktiva terhadap Struktur Modal. Populasi penelitian ini berjumlah 69 perusahaan dari sektor industri dasar dan kimia yang terdaftar di Bursa Efek Indonesia Periode 2014-2017. Hubungan likuiditas dan struktur modal yaitu mengukur kemampuan perusahaan saat membayar hutang jangka pendek dengan melihat aset lancar yang ada di perusahaan. Net profit margin akan memperoleh tambahan modal untuk perusahaan baik yang akan dimasukkan ke dalam laba ditahan maupun langsung digunakan untuk investasi. Stabilitas penjualan dapat mempengaruhi struktur modal, dengan kenaikan tingkat pertumbuhan penjualan maka dapat meningkatkan aset lancar dan meningkatkan modal yang ada di perusahaan. Hasil penelitian ini adalah Current ratio dan struktur aktiva berpengaruh dan tidak signifikan terhadap struktur modal. Net profit margin dan stabilitas penjualan tidak berpengaruh dan signifikan terhadap struktur modal. Current ratio, net profit margin, stabilitas penjualan dan struktur aktiva berpengaruh dan signifikan terhadap struktur modal.
\end{abstract}

Kata Kunci : Current Ratio, Net Profit Margin, Stabilitas Penjualan, Struktur Aktiva dan Struktur Modal.

\section{PENDAHULUAN}

\subsection{Latar Belakang}

Pada tahun 2016 ini tingkat pertumbuhan perekonomian negara Indonesia mencatat sebesar 5,02\%, lebih tinggi dibandingkan pertumbuhan perekonominya di tahun 2015 sebesar 
4,88\%. Namun, terjadinya perlambatan pertumbuhan ekonomi pada triwulan III dan triwulan IV di tahun 2016 mengakibatkan pertumbuhan ekonomi Indonesia lebih rendah dibandingkan dengan pertumbuhannya pada Semester I di tahun 2016, yang sebesar 5,06\%. Kontraksi pertumbuhan pada triwulan IV di tahun 2016 menyebabkan pertumbuhan Industri Logam Dasar melambat secara sangat berarti, yaitu dari sebesar $6,21 \%$ pada tahun 2015 menjadi hanya sebesar 0,76\% pada tahun 2016 .

Perlambatan pertumbuhan ekonomi berdampak pada sektor industri dasar dan kimia yang terdapat di Bursa Efek Indonesia terutama tingkat struktur modal yang berasal hutang meningkat. Permodalan menjadi kendala utama perusahaan dalam menjalankan kegiatan operasionalnya. Modal perusahaan berasal dari modal sendiri maupun modal dari luar dengan cara meminjam ataupun penjualan saham perusahaan di pasar modal Indonesia.

Perusahaan tidak terlepas dari tujuan utama operasi yakni laba. Net profit margin ini yang digunakan sebagai indikator dari laba. Net profit margin perusahaan dapat menghasilkan keuntungan kemudian perusahaan mencanangkan sebagai laba ditahan. Perusahaan yang memiliki net profit margin tinggi tentu penggunakan hutang sebagai pendanaan dari luar menjadi rendah.

Adapun beberapa sektor industri dasar dan kimia menghadapi masalah berkaitan dengan struktur modal yakni PT. Indocement Tunggal Prakarsa Tbk yang memiliki aktiva lancar pada tahun 2016 sebesar Rp 14.424.622.000.000 meningkat dibandingkan tahun 2015 dengan total hutang pada tahun 2016 sebesar Rp 4.011.877.000.000 meningkat dibandingkan tahun 2015. Current ratio diukur dari aktiva lancar yang meningkat seharusnya dapat menurunkan struktur modal yang diukur dari total hutang namun kenyataan aktiva lancar yang meningkat dapat meningkatkan total hutang.

PT. Ekadharma International Tbk yang memiliki laba bersih setelah pajak pada tahun 2016 sebesar Rp 90.685.821.530 meningkat dibandingkan tahun 2015 dengan total hutang pada tahun 2016 sebesar Rp 110.503.822.983 meningkat dibandingkan di tahun 2015. Net profit margin menggunakan laba bersih setelah pajak perusahaan juga meningkat seharusnya struktur modal yang diukur dari total hutang mengalami penurunan namun kenyataan laba bersih setelah pajak mengalami peningkatan yang diikuti dengan total hutang yang meningkat.

PT. Semen Gresik (Persero) Tbk yang memiliki penjualan pada tahun 2017 sebesar Rp 27.813.664.176.000 yang mengalami peningkatan dibandingkan tahun 2016 dengan total hutang pada tahun 2017 sebesar Rp 18.524.450.664.000 yang mengalami peningkatan dibandingkan tahun 2016. Stabilitas penjualan yang diukur dari penjualan yang meningkat seharusnya struktur modal yang diukur dari total hutang mengalami penurunan namun kenyataan penjualan yang meningkat justru dapat meningkat total hutang.

Total aktiva PT. Asahimas Flat Glass Tbk di tahun 2017 sebesar Rp 6.267.816.000.000 yang mengalami peningkatan dibandingkan tahun 2016 dengan total hutang pada tahun 2017 sebesar Rp 2.718.939.000.000 yang mengalami peningkatan dibandingkan 
tahun 2016. Perusahaan yang memiliki total aktiva tinggi maka struktur modal atau total hutang yang terjadi di perusahaan semakin rendah namun kenyataannya perusahaan yang memiliki total aktiva tinggi juga memiliki total hutang tinggi pula.

\subsection{Identifikasi Masalah}

Dari latar belakang di atas ini peneliti mengidentifikasi masalah yaitu :

1. Current ratio yang meningkat tidak selalu diikuti dengan menurunnya struktur modal pada perusahaan industri dasar dan kimia di Bursa Efek Indonesia Periode 2014-2017.

2. Net profit margin yang meningkat tidak selalu diikuti dengan menurunnya struktur modal pada perusahaan industri dasar dan kimia di Bursa Efek Indonesia Periode 20142017.

3. Stabilitas penjualan yang meningkat tidak selalu diikuti dengan menurunnya struktur modal pada perusahaan industri dasar dan kimia di Bursa Efek Indonesia Periode 20142017.

4. Struktur aktiva yang meningkat tidak selalu diikuti dengan menurunnya struktur modal pada perusahaan industri dasar dan kimia di Bursa Efek Indonesia Periode 2014-2017.

5. Current ratio, net profit margin, stabilitas penjualan dan struktur aktiva yang meningkat tidak selalu diikuti dengan menurunnya struktur modal pada perusahaan industri dasar dan kimia di Bursa Efek Indonesia Periode 2014-2017.

\subsection{Perumusan Masalah}

Berdasarkan latar belakangnya maka masalah penelitian ini sebagai berikut :

1. Apakah current ratio berpengaruh terhadap struktur modal pada perusahaan industri dasar dan kimia di Bursa Efek Indonesia periode 20142017?

2. Bagaimana net profit margin berpengaruh terhadap struktur modal pada perusahaan industri dasar dan kimia di Bursa Efek Indonesia periode 2014- 2017?

3. Bagaimana stabilitas penjualan berpengaruh terhadap struktur modal pada perusahaan industri dasar dan kimia di Bursa Efek Indonesia periode 2014- 2017?

4. Bagaimana struktur aktiva berpengaruh terhadap struktur modal pada perusahaan industri dasar dan kimia di Bursa Efek Indonesia periode 20142017?

5. Bagaimana current ratio, net profit margin, stabilitas penjualan dan struktur aktiva berpengaruh terhadap struktur modal pada perusahaan industri dasar dan kimia di Bursa Efek Indonesia periode 2014-2017

\section{TINJAUAN PUSTAKA}

\subsection{Pengaruh Current Ratio Terhadap Struktur Modal}

(Herlambang \& Marwoto, 2014) menyatakan perusahaan mampu membayar hutang lancarnya dengan baik maka perusahaan berada pada kondisi likuid namun perusahaan tidak mampu membayar hutang lancarnya dengan baik menunjukkan perusahaan berada pada kondisi ilikuid.

(Wadati \& Nafisah, 2017) menyatakan bahwa likuiditas yang tinggi maka hutang lancarnya juga kecil. Berdasarkan packing order theory perusahaan lebih senang menggunakan modal sendiri terlebih dahulu.

(Hudan, Isynuwardhana , \& 
Triyanto, 2016) berpendapat likuiditas tinggi dapat meminimalkan penggunaan dana dari hutang.

\subsection{Pengaruh Net Profit Margin terhadap Struktur Modal}

(Kamaludin \& Indriani, 2012) berpendapat profitabilitas tinggi tentu laba ditahan besar sehingga penggunaan hutang juga rendah.

(Fatimatuz \& Suwitho, 2016) berpendapat perusahaan memiliki tujuan utama adalah mendapatkan profit sebesarbesarnya, maka keuntungan tersebut dapat meminimalkan penggunaan hutang.

(Siregar \& Fahmi, 2018) menyatakan profitabilitas yang tinggi akan menaikan nilai struktur modal perusahaan

\subsection{Pengaruh Stabilitas Penjualan Terhadap Struktur Modal}

(Kamaludin \& Indriani, 2012) menyatakan penjualan relatif stabil memudahkan perusahaan melakukan pinjaman dan mampu membayar beban yang tinggi.

(Sudana, 2015) penjualan stabil dapat memperoleh pinjaman dengan hutang yang tinggi dibandingkan perusahaan yang memiliki penjualan naik turun.

\[ \text { Halim, 2015) } \begin{array}{r}\text { menyatakan, } \\ \text { kemungkinan } \\ \text { penjualan } \\ \text { menggunakan hutang sebagai pendanaan } \\ \text { juga besar. }\end{array} \]

\subsection{Pengaruh Struktur Aktiva \\ Terhadap Struktur Modal}

Berdasarkan pendapat (Kamaludin \& Indriani, 2012) aktiva tetap yang dimiliki perusahaan besar dengan menggunakan hutang besar dan aktiva tetap ini digunakan sebagai jaminan dalam memperoleh dana pinjaman.

(Wadati \& Nafisah, 2017) menyatakan besarnya struktur aktiva bagi perusahaan besar cenderung memiliki hutang yang besar karena sejumlah altiva tetap yang ada di perusahaan dapat menjamin pembayaran hutang.

(Andi, 2016) berpendapat pertumbuhan aktiva tinggi sehingga penggunaan utang sebagai struktur modal dari luar tinggi dibandingkan perusahaan yang aktivanya rendah.

\section{METODOLOGI PENELITIAN}

\subsection{Metodologi Penelitian}

Pendekatan penelitian kuantitatif. Bersifat hubungan sebab akibat, yaitu pengaruh variabel independen terhadap variabel dependen.

Teknik pengumpulan data adalah kepustakaan dan penelitian lapangan dengan mengumpulkan laporan keuangan sektor industri dasar dan kimia di Bursa Efek Indonesia Periode 20142017.

\subsection{Populasi dan Sampel}

Populasi penelitian ini berjumlah 69 industri dasar dan kimia di Bursa Efek Indonesia Periode 2014-2017. Kriteria pemilihan sampel penelitian sebagai berikut:

1. Industri dasar dan kimia di Bursa Efek Indonesia Periode 2014-2017.

2. Industri dasar dan kimia di Bursa Efek Indonesia yang menerbitkan laporan keuangan Periode 20142017.

3. Industri dasar dan kimia di Bursa Efek Indonesia yang memiliki laba Periode 2014-2017.

Sampel penelitian sebanyak 31 
industri dasar dan kimia di Bursa Efek Indonesia Periode 2014-2017. Penentuan sampel penelitian dengan menggunakan kriteria tertentu disajikan pada tabel 3.1 sebagai berikut:

Tabel 3.1 Sampel Penelitian

\begin{tabular}{|c|l|c|}
\hline No. & \multicolumn{1}{|c|}{ Kriteria } & $\begin{array}{c}\text { Jumlah } \\
\text { Sampel }\end{array}$ \\
\hline 1. & $\begin{array}{l}\text { Industri dasar dan kimia di } \\
\text { Bursa Efek Indonesia Periode } \\
2014-2017 .\end{array}$ & 69 \\
\hline 2. & $\begin{array}{l}\text { Industri dasar dan kimia di } \\
\text { Bursa Efek Indonesia yang } \\
\text { tidak menerbitkan laporan } \\
\text { keuangan Periode 2014-2017. }\end{array}$ & $(5)$ \\
\hline 3. & $\begin{array}{l}\text { Industri dasar dan kimia di Bursa } \\
\text { Efek Indonesia yang mengalami } \\
\text { kerugian selama Periode 2014- } \\
\text { 2017 }\end{array}$ & $(33)$ \\
\hline Jumlah Sampel Perusahaan & 31 \\
\hline Jumlah Sampel 31 x 4 tahun & $\mathbf{1 2 4}$ \\
\hline
\end{tabular}

\subsection{Definisi Operasional}

1. Current Ratio adalah suatu rasio menunjukkan kemampuannya dalam membayar hutang jangka pendek dengan aktiva jangka pendeknya dalam waktu dekat. (Margaretha, 2011)

Current ratio $=$ Current Assets

\section{Current Assets Current Liabilities}

2. Net Profit Margin merupakan rasio untuk membandingkan antara margin laba dengan penjualan. (Kasmir, 2014)

Profit Margin $=$ Penjualan Bersih - Harga Pokok Penjualan

\section{Penjualan}

3. Stabilitas Penjualan merupakan penjualan stabil yang membandingkan penjualan tahun ini dengan tahun lalu.
(Fahmi, 2012)

Kenaikan Penjualan $=$ Penjualan tahun ini - Penjualan tahun lalu

tahun lalu

\section{Penjualan}

4. Struktur Aktiva adalah rasio yang membandingkan total aktiva tetap dengan keseluruhan total aktiva yang dimilikinya (Halim, 2015)

\begin{tabular}{c} 
Struktur Aktiva $=$ Total Aktiva \\
Tetap \\
\hline
\end{tabular}

Total Aktiva

5. Struktur Modal adalah perbandingan antara total hutang dengan ekuitas perusahaan. (Ambarwati, 2010)

$$
\mathrm{DER}=\frac{\text { Total Debt }}{\text { Equity }}
$$

\section{$3.4 \quad$ Uji Asumsi Klasik}

\section{Uji Normalitas}

Uji normalitas digunakan untuk menguji model regresi yang dipakai normal atau tidak. Pengambilan keputusan data normal atau tidak dengan kriteria :

1) Jika sig. > 0,05 maka terdistribusi data normal.

2) Jika sig. < 0,05 maka terdistribusi data tidak normal

\section{Uji Multikolinearitas}

Pengujian multikolinearitas menunjukkan terdapat korelasi linear dua atau lebih variabel independen. Apabila tolerance > 0,10 dan VIF $<10$ maka tidak terjadi multikolinearitas.

\section{Uji Heteroskedastisitas}

Uji heteroskesdastisitas berguna untuk 
menguji terdapat ketidaksamaan varians dari pengamatan ke pengamatan lainnya. Pengujian heretokedastisitas dapat dilakukan dengan melihat pada gratik scatter plot. Cara untuk mendeteksi atau tidaknya heteroskedastisitas dengan melihat ada tidaknya pola tertentu pada grafik scatterplot antara nilai prediksi variabel terikat dengan residualnya dimana sumu $\mathrm{Y}$ adalah $\mathrm{Y}$ yang telah diprediksi, dan sumbu $X$ adalah residual (Y prediksi - Y sesungguhnya).

Pengujian statistik heteroskedastisitas dapat dilakukan dengan uji gletser.

\section{Uji Autokorelasi}

Pengujian autokorelasi untuk melihat adanya hubungan antara data (observasi) satu dengan data yang lainnya dalam 1 variabel. Pengujian autokorelasi dengan menggunakan metode grafik maupun uji Durbin Waston (DW).

1. Pengujian Hipotesis

Pengujian hipotrsis dapat dilakukan analisis regresi linear berganda dikarenakan variabel bebas lebih satu variabel. Model regresi linear berganda yakni:

$$
Y=a+b_{1} X_{1}+b_{2} X_{2}+b_{3} X_{3}+b_{4} X_{4}+e
$$

\section{Keterangan :}

$\begin{array}{ll}\mathrm{Y} & : \text { Struktur Modal } \\ \mathrm{a} & : \text { konstanta } \\ \mathrm{X}_{1} & : \text { Current ratio } \\ & \\ \mathrm{X}_{3} & : \text { Stabilitas Penjualan } \\ \mathrm{X}_{2} & : \text { Net profit margin } \\ \mathrm{X}_{4} & : \text { Struktur Aktiva }\end{array}$

$\mathrm{b}_{1,2,3,4}$ : besaran koefisien regresi dari masing-masing variabel

$$
\text { e : error }
$$

Hipotesis dalam penelitian ini menggunakan F-test dan t-test:

1. Uji Signifikan Simultan (F-test)
Uji F berguna mengetahui hubungan linear antara keseluruhan variabel bebas secara bersama-sama (simultan) terhadap variabel dependen. Nilai Fhitung akan dibandingkan dengan $F_{\text {tabel }}$ pada tingkat signifikan $(\alpha)=5 \%$. Kriteria penilaian hipotesis pada uji-F ini

\begin{tabular}{|c|c|c|c|c|c|}
\hline & & Descripti & e Statistics & & \\
\hline & $\mathrm{N}$ & Minimum & Maximum & Mean & $\begin{array}{c}\text { Std. } \\
\text { Deviation }\end{array}$ \\
\hline$\overline{\mathrm{CR}}$ & 124 & ,79 & 15,16 & 2,8835 & 2,80975 \\
\hline PM & 124 & 1,02 & 1,84 & 1,2677 & ,17389 \\
\hline SP & 124 &,- 38 & ,54 & ,0683 & , 15944 \\
\hline SA & 124 & ,02 & ,80 & ,3922 & , 18905 \\
\hline DER & 124 & ,07 & 7,99 & 1,0724 & 1,18725 \\
\hline $\begin{array}{l}\text { Valid N } \\
\text { (listwise) }\end{array}$ & 124 & & & & \\
\hline
\end{tabular}
adalah:

$\mathrm{H}_{0}$ diterima apabila $\mathrm{F}_{\text {hitung }} \leq \mathrm{F}_{\text {tabel }}$

$\mathrm{H}_{1}$ diterima apabila $\mathrm{F}_{\text {hitung }}>\mathrm{F}_{\text {tabel }}$

2. Uji Signifikan parsial (t-test)

Uji t-test berguna menguji pengaruh antara satu variabel independen terhadap variabel dependen. Tingkat signifikan yang digunakan sebesar $5 \%$.

Kriteria pengambilan keputusan pada uji-t ini adalah:

$\mathrm{H}_{0}$ diterima jika : $\mathrm{t}_{\text {hitung }} \leq \mathrm{t}_{\text {tabel }} \leq \mathrm{t}_{\text {hitung }}$

$\mathrm{H}_{1}$ diterima jika : $t_{\text {hitung }}>\mathrm{t}_{\text {tabel }}$

$$
t_{\text {hitung }} \leq \text { - } t_{\text {tabel }}
$$

3. Uji Koefisien Determinasi

Pengujian koefisien determinansi $\left(\mathrm{R}_{2}\right)$ berguna untuk mengetahui persentase besarnya pengaruh variabel independen terhadap variabel dependen. Koefisien determinasi mendekati 1 maka tingkat pengaruhnya kuat. 


\section{IV .HASIL DAN PEMBAHASAN}

\subsection{Deskripsi Data}

Berdasarkan statistik deskriptif digunakan untukpenelitian ini adalah :

\section{Tabel 4.1: Statistik Deskriptif}

\section{Berdasarkan $\quad$ Tabel $\quad 4.1$} menunjukkan nilai minimum, nilai maksimum, nilai rata-rata (mean), dan standar deviasi untuk variabel current ratio, net profit margin, stabilitas penjualan, struktur aktiva dan struktur modal dengan rincian sebagai berikut:

1. Variabel current ratio dengan jumlah sampel sebanyak 124 , nilai minimum 0,79 pada PT. Tembaga Mulia Semanan Tbk tahun 2014 dan nilai maksimum 15,16 pada PT. Duta Pertiwi Nusantara Tbk tahun 2016 sedangkan nilai rata-rata (mean) 2,8835 dengan standar deviasi 2,80975 .

2. Variabel net profit margin dengan jumlah sampel sebanyak 124, nilai minimum 1,02 pada PT. Tembaga Mulia Semanan Tbk tahun 2014 dan nilai maksimum 1,84 pada PT. Indocement Tunggal Prakarsa Tbk tahun 2014 sedangkan nilai rata-rata (mean) 1,2677 dengan standar deviasi 0,17389 .

3. Variabel stabilitas penjualan dengan jumlah sampel sebanyak 124, nilai minimum $-0,38$ pada PT. Tri Polyta Indonesia Tbk tahun 2014 dan nilai maksimum 0,54 pada PT. Wijaya Karya Beton, Tbk tahun 2017 sedangkan nilai rata-rata (mean) 0,0683 dengan standar deviasi 0,15944 .

4. Variabel struktur aktiva dengan jumlah sampel sebanyak 124 , nilai minimum 0,02 pada PT. Indah Kiat Pulp \& Paper Tbk tahun 2017 dan nilai maksimum 0,80 pada PT. Semen Baturaja Persero Tbk tahun 2016 sedangkan nilai rata- rata (mean) 0,3922 dengan standar deviasi 0,18905 .

5. Variabel struktur modal dengan jumlah sampel sebanyak 124, nilai minimum 0,07 pada PT. Semen Baturaja Persero Tbk tahun 2014 dan nilai maksimum 7,99 pada PT. Tembaga Mulia Semanan Tbk tahun 2014 sedangkan nilai ratarata (mean) 1,0724 dengan standar deviasi 1,18725 .

\subsection{Pengujian Asumsi Klasik}

\subsubsection{Pengujian Normalitas}

Pengujian normalitas untuk menguji data sudah terdistribusi normal atau tidak normal. Pengujian normalitas menggunakan grafik histogram yaitu :

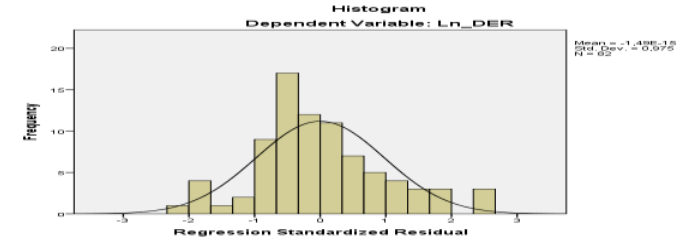

Gambar 4.1 Histogram

Berdasarkan Gambar 4.1 menunjukkan data histogram berdistribusi normal terlihat arah histogram tidak miring ke kanan maupun ke kiri dan membentuk lonceng terbalik.

Demikian pula dengan hasil normal probability plot berikut ini:

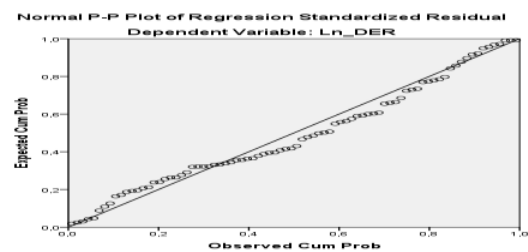

Gambar 4.2:Normal Probability Plot

Berdasarkan Gambar 4.2 normal probability plot terlihat titik-titik mendekati garis diagonal maka data berdistribusi normal.

Pengujian normalitas dengan cara statistik non parametrik Kolmogorov Smirnov Test dengan syarat sebagai berikut: 
- Jika nilai signifikan >0,05 maka distribusi normal,

- Jika nilai signifikan <0,05 maka distribusi tidak normal.

Hasil dari uji normalitas dengan menggunakan statistic Kolmogorov Smirnov Test :

Tabel 4.2: One-Sample KolmogorovSmirnov Test

Unstandardized

Residual

\begin{tabular}{llr}
\hline $\mathrm{N}$ & \multicolumn{2}{c}{82} \\
\hline Normal \\
Parameters
\end{tabular}

a. Test distribution is Normal.

b. Calculated from data.

c. Lilliefors Significance Correction.

d. This is a lower bound of the true significance.

d. This is a lower bound of the true significance.

Berdasarkan 4.2 Tabel One-Sample Kolmogorov-Smirnov Test menunjukkan current ratio, net profit margin, stabili penjualan, struktur aktiva dan struk modal memiliki nilai sig $0,200>0$ sehingga data memenuhi syarat distrib normal.

\subsubsection{Uji Multikolinearitas}

Pengujian multikolinearitas un mengetahui ada tidaknya multikolineari dalam dilihat dari nilai tolerance ( variance inflation factor. $\mathrm{C}$ pengambilan keputusan yaitu nilai $\mathrm{VIF} \leq \ldots$ dan nilai tolerance $\geq 0,10$ maka regresi bebas multikolinieritas. VIF adalah satu dibanding tolerance.

Tabel 4.3: Hasil Uji Multikolinearitas Model Collinearity Statistics

\begin{tabular}{ll|r|r} 
& & Tolerance & \multicolumn{1}{l}{ VIF } \\
\hline 1 & (Constant) & & \\
\cline { 2 - 4 } & Ln_CR &, 668 & 1,496 \\
\cline { 2 - 4 } & Ln_PM &, 719 & 1,391 \\
\cline { 2 - 4 } & Ln_SP &, 975 & 1,025 \\
\hline & Ln_SA &, 925 & 1,082 \\
\hline
\end{tabular}

Berdasarkan Tabel 4.3 diatas menunjukkan nilai tolerance variabel current ratio, net profit margin, stabilitas penjualan, struktur aktiva lebih besar dari 0,1 menunjukkan tidak terjadi multikolinearitas. Nilai VIF untuk variabel current ratio, net profit margin, stabilitas penjualan, struktur aktiva lebih kecil 10 menunjukkan tidak terjadi multikolinearitas.

\subsubsection{Uji Autokorelasi}

Pengujian autokorelasi untuk menguji apakah terdapat ada korelasi antara kesalahan pengganggu pada periode $t$ dengan kesalahan pengganggu pada periode t-1 (periode sebelumnya). Jika terjadi korelasi menunjukkan ada problem autokorelasi. Pengujian autokorelasi dapat menggunakan uji Durbin-Watson (DWtest). Pengujian autokorelasi dengan uji Durbin-Watson :

\section{Tabel 4.4 : Hasil Uji Autokorelasi}

\begin{tabular}{|c|c|c|c|c|c|}
\hline \multicolumn{6}{|c|}{ Model Summary $^{\text {b }}$} \\
\hline Model & $\mathrm{R}$ & $\begin{array}{c}\mathrm{R} \\
\text { Square }\end{array}$ & $\begin{array}{c}\text { Adjusted } \\
\text { R } \\
\text { Square }\end{array}$ & $\begin{array}{c}\text { Std. } \\
\text { Error of } \\
\text { the } \\
\text { Estimate }\end{array}$ & $\begin{array}{l}\text { Durbin- } \\
\text { Watson }\end{array}$ \\
\hline 1 &, $927^{\mathrm{a}}$ & 858 & 851 &, 36212 & 1,981 \\
\hline \multicolumn{6}{|c|}{$\begin{array}{l}\text { a. Predictors: (Constant), Ln_SA, Ln_PM, Ln_SP, } \\
\text { Ln_CR }\end{array}$} \\
\hline \multicolumn{6}{|c|}{ b. Dependent Variable: Ln_DER } \\
\hline
\end{tabular}

Berdasarkan tabel 4.4 menunjukkan nilai DW sebesar 1,981. Pengujian autokorelasi adalah du $<\mathrm{dw}<4-\mathrm{du}$. Sampel penelitian sebanyak 82 maka nilai $\mathrm{dl}=1.5406$ dan nilai $\mathrm{du}=1.7446$. Hasil pengukurannya adalah du $<\mathrm{dw}<4-\mathrm{du}$ 
maka $1.7446<1,981<(4-1.7446)$ sehingga $1.7446<1,981<2,2554$ sehingga disimpulkan tidak terjadi autokorelasi dalam penelitian ini.

\subsubsection{Uji Heteroskedastisitas}

Pengujian heteroskedastisitas untuk menguji apakah model regresi terjadi ketidaksamaan varian berasal dari residual satu pengamatan ke pengamatan yang lain. Pengujian heteroskedastisitas dengan melihat grafik Scatterplot sebagai berikut :

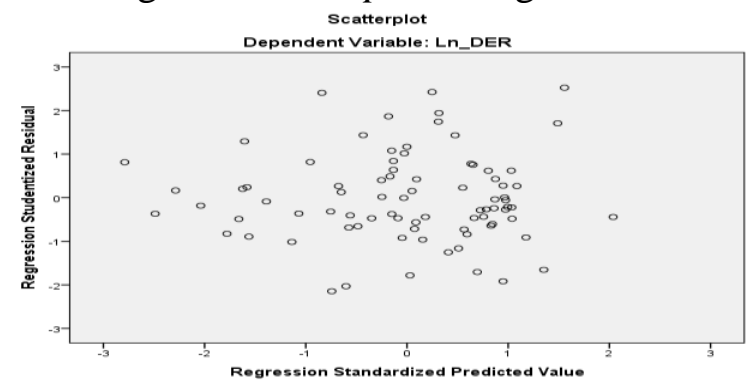

Gambar 4.3: Scatterplot

Berdasarkan Gambar

menunjukkan titik tersebar secara acak dan tidak membentuk suatu pola tertentu sehingga tidak terjadi heteroskedastisitas.

Pendeteksian ada tidaknya heteroskedastisitas dengan menggunakan metode glejser sebagai berikut :

Tabel 4.5 : Uji Glejser

\begin{tabular}{|c|c|c|c|c|c|c|}
\hline \multicolumn{7}{|c|}{ Coefficients $^{\mathrm{a}}$} \\
\hline & & \multicolumn{2}{|c|}{$\begin{array}{l}\text { Unstandardized } \\
\text { Coefficients }\end{array}$} & \multirow{2}{*}{$\begin{array}{c}\text { Standardized } \\
\text { Coefficients } \\
\text { Beta } \\
\end{array}$} & \multirow[b]{2}{*}{$\mathrm{t}$} & \multirow[b]{2}{*}{ Sig. } \\
\hline \multicolumn{2}{|c|}{ Model } & B & $\begin{array}{l}\text { Std. } \\
\text { Error }\end{array}$ & & & \\
\hline 1 & (Constant) &, 415 &, 089 & & 4,650 &, 000 \\
\hline & Ln_CR &,- 014 & 047 &,- 041 &,- 298 & ,766 \\
\hline & Ln_PM &,- 213 & ,254 &,- 111 &,- 841 & 403 \\
\hline & Ln_SP & ,021 & 022 & , 108 & ,953 & 344 \\
\hline & Ln_SA & ,030 & ,042 & ,082 & ,704 & , 483 \\
\hline
\end{tabular}

Berdasarkan Tabel 4.5 menunjukkan nilai signifikan current ratio, net profit margin, stabilitas penjualan, struktur aktiva berada di atas 0,05 sehingga tidak terjadi Heteroskedastisitas.

\subsection{Hasil Analisis Data}

4.3.1 Analisis Regresi Linier Berganda
Analisis regresi linear berganda berguna untuk memprediksi perubahan (naik - turunnya) variabel dependen dihubungkan oleh dua atau lebih variabel independen sebagai faktor prediktor untuk mengetahui ada tidaknya pengaruh antara variabel independen terhadap variabel dependen. Hasil analisis regresi berganda dapat dilihat pada tabel 9 berikut ini:

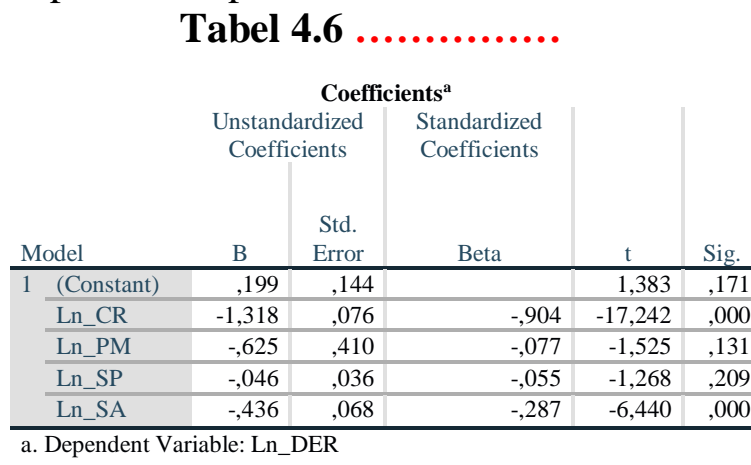

Berdasarkan tabel 4.6 diatas diperoleh rumus regresi sebagai berikut: Ln_DER $=0,199$ - 1,318 Ln_CR - 0,625 Ln_PM - 0,046 Ln_SP $-0,436$ Ln_SA $+\varepsilon$ Hasil interpretasi dari regresi tersebut adalah sebagai berikut:

1. Nilai a sebesar 0,199 artinya jika current ratio, net profit margin, stabilitas penjualan, struktur aktiva dianggap konstan, maka struktur modal sebesar 0,199.

2. Nilai koefisien current ratio $\left(\mathrm{X}_{1}\right)$ adalah -1,318 menunjukkan tiap peningkatan current ratio satu kali maka struktur modal mengalami penurunan sebesar 1,318.

3. Nilai koefisien net profit margin $\left(\mathrm{X}_{2}\right)$ sebesar - 0,625 menunjukkan tiap peningkatan net profit margin satu kali maka struktur modal mengalami penurunan sebesar 0,625 .

4. Nilai koefisien stabilitas penjualan $\left(\mathrm{X}_{3}\right)$ sebesar -0,046 menunjukkan tiap peningkatan stabilitas penjualan satu kali maka struktur modal mengalami penurunan sebesar 0,046 . 
5. Nilai koefisien struktur aktiva $\left(\mathrm{X}_{3}\right)$ sebesar -0,436 menunjukkan tiap peningkatan struktur aktiva satu kali maka struktur modal mengalami penurunan sebesar 0,436 .

\subsubsection{Koefisien Determinasi $\left(R^{2}\right)$}

Pengujian koefisien determinasi untuk mengetahui seberapa besar kemampuan pengaruh variabel bebas terhadap variabel terikat. Semakin besar nilai adjusted $\mathrm{R}$ Square koefisien determinasi, maka semakin baik varian dan variabel bebas menerangkan variabel terikat. Pengujian koefisien determinasi sebagai berikut :

Tabel 4.7: Koefisien Determinasi Model Summary ${ }^{\mathrm{b}}$

\begin{tabular}{|c|c|c|c|c|}
\hline \multicolumn{5}{|c|}{ Model Summary ${ }^{\circ}$} \\
\hline $\begin{array}{l}\text { Mode } \\
1\end{array}$ & $\mathrm{R}$ & $\begin{array}{l}\mathrm{R} \\
\text { Squar } \\
\mathrm{e}\end{array}$ & $\begin{array}{l}\text { Adjuste } \\
\text { d R } \\
\text { Square }\end{array}$ & $\begin{array}{l}\text { Std. } \\
\text { Error of } \\
\text { the } \\
\text { Estimat } \\
\text { e }\end{array}$ \\
\hline 1 & $\begin{array}{r}927 \\
\text { a }\end{array}$ & ,858 & ,851 & ,36212 \\
\hline
\end{tabular}

a. Predictors: (Constant), Ln_SA, Ln_PM, Ln_SP, Ln_CR

b. Dependent Variable: Ln_DER

Berdasarkan Tabel 4.7 diatas diperoleh nilai Adjusted $R$ Square koefisien determinasi sebesar 0,851 atau $85,1 \%$. Variabel independen dipengaruhi oleh struktur modal sebesar $85,1 \%$ dan sisanya sebesar 14,9\% dipengaruhi oleh variabel lain yang tidak diteliti seperti ukuran perusahaan, pertumbuhan penjualan dan kebijakan dividen.

\subsubsection{Pengujian Hipotesis Secara Simultan (Uji Statistik F)}

Pengujian F untuk menguji apakah variabel independen secara bersama-sama mempengaruhi variabel dependen. Berdasarkan hasil pengolahan data dengan program SPSS, maka diperoleh hasil uji $\mathrm{F}$ sebagai berikut :
Tabel 4.8. Hasil Uji F

\begin{tabular}{|c|c|c|c|c|c|c|}
\hline \multicolumn{7}{|c|}{ ANOVA $^{a}$} \\
\hline \multicolumn{2}{|c|}{ Model } & $\begin{array}{l}\text { Sum of } \\
\text { Squares }\end{array}$ & $\mathrm{df}$ & $\begin{array}{l}\text { Mean } \\
\text { Square }\end{array}$ & $\mathrm{F}$ & Sig. \\
\hline \multirow[t]{3}{*}{1} & Regression & 61,249 & 4 & 15,312 & 116,771 &, $000^{\mathrm{b}}$ \\
\hline & Residual & 10,097 & 77 & ,131 & & \\
\hline & Total & 71,346 & 81 & & & \\
\hline
\end{tabular}

Dari Tabel 4.8 diatas, dapat dilihat hasil $F_{\text {hitung }}$ sebesar 116,771 dengan nilai signifikan 0,000 , sedangkan $F_{\text {tabel }}$ sebesar 2,49 maka nilai $F_{\text {hitung }}>F_{\text {tabel }}$ yaitu 116,771 $>$ 2,49 sehingga $\mathrm{H}_{0}$ ditolak dan $\mathrm{H}_{1}$ diterima, artinya variabel Current ratio, net profit margin, stabilitas penjualan dan struktur aktiva berpengaruh dan signifikan terhadap struktur modal pada perusahaan industri dasar dan kimia di Bursa Efek Indonesia periode 2014-2017.

\subsubsection{Pengujian Hipotesis Secara Parsial (Uji Statistik t)}

Pengujian $t$ untuk menguji apakah variabel independen secara masing-masing mempengaruhi variabel dependen. Pengujian t sebagai berikut :

Tabel 4.9: Hasil Uji Statistik t Coefficients $^{\mathrm{a}}$

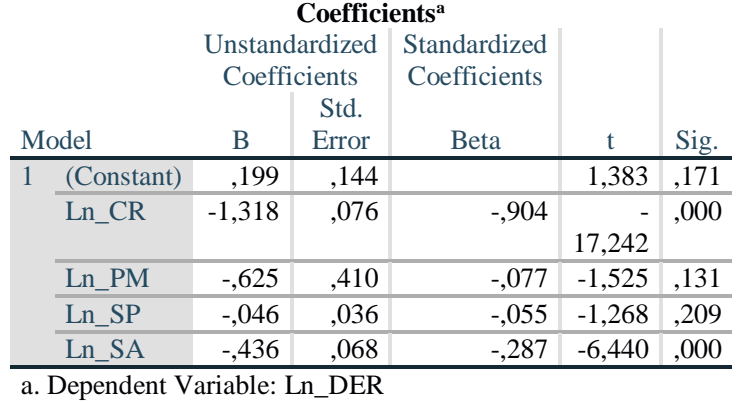

1. Berdasarkan Tabel 4.9 diatas menunjukkan variabel current ratio mempunyai nilai $t_{\text {hitung }}$ sebesar $-17,242$ dengan nilai signifikan 0,000, sedangkan $t_{\text {tabel }}$ sebesar 1,990 sehingga $-t_{\text {hitung }}<-t_{\text {tabel }}$ yaitu $-17,242<-1,990$ maka Ho diterima dan $\mathrm{H}_{1}$ ditolak, artinya variabel Current ratio berpengaruh dan tidak signifikan terhadap struktur modal pada 
perusahaan industri dasar dan kimia di Bursa Efek Indonesia periode 20142017.

2. Variabel net profit margin mempunyai nilai thitung $-1,525$ dengan nilai signifikan 0,131 , sedangkan $t_{\text {tabel }}$ sebesar 1,990 dengan signifikan 0,05 maka $-t_{\text {hitung }}>$. $t_{\text {tabel }}$ yaitu $-1,525>$ 1,990 sehingga Ho ditolak dan $\mathrm{H}_{1}$ diterima, artinya variabel net profit margin tidak berpengaruh dan signifikan terhadap struktur modal pada perusahaan industri dasar dan kimia di Bursa Efek Indonesia periode 2014-2017.

3. Variabel stabilitas penjualan mempunyai nilai thitung $-1,268$ dengan nilai signifikan 0,209 sedangkan $t_{\text {tabel }}$ sebesar 1,990 dengan signifikan 0,05 maka $-t_{\text {hitung }}>-t_{\text {tabel }}$ yaitu $-1,268>-1,990$ sehingga $\mathrm{H}_{0}$ ditolak dan $\mathrm{H}_{1}$ diterima artinya variabel stabilitas penjualan tidak berpengaruh dan signifikan terhadap struktur modal pada perusahaan industri dasar dan kimia di Bursa Efek Indonesia periode 20142017.

4. Variabel struktur aktiva mempunyai nilai thitung $-6,440$ dengan nilai signifikan 0,000 sedangkan $t_{\text {tabel }}$ sebesar 1,990 dengan signifikan 0,05 maka $t_{\text {hitung }}<-t_{\text {tabel }}$ yaitu $-6,440<-1,990$ sehingga $\mathrm{H}_{0}$ ditolak dan $\mathrm{H}_{1}$ diterima artinya struktur aktiva berpengaruh dan tidak signifikan terhadap struktur modal pada perusahaan industri dasar dan kimia di Bursa Efek Indonesia periode 2014-2017.

\subsection{Pembahasan}

\subsubsection{Pengaruh Current Ratio Terhadap Struktur Modal}

Hasil penelitian ini konsisten dengan pendapat (Hudan, Isynuwardhana , \& Triyanto, 2016) likuiditas tinggi akan mengurangi pendanaaan berasal dari utang. Hal ini menunjukkan pendanaan sumber internal tinggi berasal dari aset yang likuid, maka semakin tinggi likuiditas perusahaan dapat menurunkan penggunaan dana eksternal perusahaan yang berasal dari hutang.

Current ratio berpengaruh dan tidak signifikan terhadap struktur modal dikarenakan perusahaan yang memiliki aktiva lancar yang tinggi dapat menurunkan struktur modal perusahaan namun tidak signifikan diakibatkan current ratio perusahaan kebanyakan berasal dari piutang dan persediaan.

\subsubsection{Pengaruh Net Profit Margin Terhadap Struktur Modal}

Hasil penelitian ini tidak konsisten dengan teori (Kamaludin \& Indriani, 2012) mengenai profitabilitas tahun sebelumnya dapat dijadikan sebagai dasar menentukan struktur modal di tahun mendatang. Profitabilitas tinggi dapat mencanangkan sebagian laba sebagai laba ditahan, sehingga perusahaan lebih senang menggunakan laba ditahan sebelumnya daripada menggunakan hutang.

Net profit margin tidak berpengaruh dan signifikan terhadap struktur modal dikarenakan perusahaan tidak menggunakan laba tetapi menggunakan total aktiva yang dimiliki perusahaan daripada menggunakan struktur modal yang berasal hutang.

\subsubsection{Pengaruh Stabilitas Penjualan Terhadap Struktur Modal}

Hasil penelitian ini tidak konsisten dengan teori (Kamaludin \& Indriani, 2012), penjualan yang stabil lebih banyak menggunakan pinjaman daripada menanggung beban tetap yang lebih tinggi dibandingkan penjualannya tidak stabil.. 
Stabilitas penjualan tidak berpengaruh dan signifikan terhadap struktur modal dikarenakan tingkat laba yang tinggi dapat mengurangi bagian laba yang ditahan sehingga secara keseluruhan adanya peningkatan penjualan tidak cukup signifikan mempengaruhi struktur modal.

\subsubsection{Pengaruh Struktur Aktiva Terhadap Struktur Modal}

Hasil penelitian ini konsisten dengan teori (Kamaludin \& Indriani, 2012) mengenai aktiva tetap perusahaan dalam jumlah besar dapat mendorong perusahaan menggunakan hutang besar.

Struktur aktiva berpengaruh dan tidak signifikan terhadap struktur modal dikarenakan struktur aktiva yang dimiliki perusahaan tinggi sehingga dapat digunakan sebagai jaminan untuk memperoleh pendanaaan dari ekternal perusahaan.

\section{KESIMPULAN}

1. Current ratio berpengaruh dan tidak signifikan terhadap struktur modal pada perusahaan industri dasar dan kimia di Bursa Efek Indonesia periode 20142017.

2. Net profit margin tidak berpengaruh dan signifikan terhadap struktur modal pada perusahaan industri dasar dan kimia di Bursa Efek Indonesia periode 20142017

3. Stabilitas penjualan tidak berpengaruh dan signifikan terhadap struktur modal pada perusahaan industri dasar dan kimia di Bursa Efek Indonesia periode 2014-2017.

4. Struktur aktiva berpengaruh dan tidak signifikan terhadap struktur modal pada perusahaan industri dasar dan kimia di Bursa Efek Indonesia periode 20142017.

5. Current ratio, net profit margin, stabilitas penjualan dan struktur aktiva berpengaruh dan signifikan terhadap struktur modal pada perusahaan industri dasar dan kimia di Bursa Efek Indonesia periode 2014-2017.

\section{DAFTAR PUSTAKA}

Ambarwati, S. (2010). Manajemen Keuangan Lanjut. Yogyakarta: Penerbit Graha Ilmu.

Andi, K. (2016). Pengaruh Profitabilitas, Struktur Aset, Pertumbuhan Penjualan Dan Ukuran Perusahaan Terhadap Struktur Modal Perusahaan Manufaktur Di Bursa Efek Indonesia. Infokam Nomor $I$ (pp. 49-57). Semarang: Infokam.

Fahmi, I. (2012). Pengantar Manajemen Keuangan. Bandung: Penerbit Alfabeta.

Fatimatuz, Z., \& Suwitho. (2016). Pengaruh Ukuran Perusahaan, Pertumbuhan Aset, Dan Profitabilitas Terhadap Struktur Modal. Jurnal Ilmu dan Riset Manajemen (pp. 1-15). Surabaya: Sekolah Tinggi Ilmu Ekonomi Indonesia (STIESIA).

Halim, A. (2015). Manajemen Keuangan Bisnis Konsep dan Aplikasinya. Jakarta: Penerbit Mitra Wacana Media.

Herlambang, S., \& Marwoto, B. H. (2014). Pengantar Ilmu Bisnis Cara Mudah Memahami Ilmu Bisnis. Yogyakarta: Penerbit Parama Publishing.

Hudan, Y., Isynuwardhana, D., \& Triyanto, D. N. (2016). Pengaruh Profitabilitas, Likuiditas Dan Ukuran Perusahaan Terhadap Struktur Modal(Studi Pada Perusahaan Pertambangan Sektor Batubara Yang Terdaftar Di Bursa Efek Indonesia Tahun 2011-2015). $e$ Proceeding of Management (pp. 15961602). Bandung: Universitas Telkom. 
Kamaludin, K., \& Indriani, R. (2012). Manajemen Keuangan. Bandung: CV. Mandar Maju.

Kasmir, K. (2014). Analisis Laporan Keuangan. Jakarta: Penerbit Rajagrafindo Persada.

Margaretha, F. (2011). Manajemen Keuangan Untuk Manajer Non Keuangan. Jakarta: Penerbit Erlangga.

Siregar, H., \& Fahmi, M. (2018). Analisis Struktur Aktiva, Net Profit Margin,Dan Current Ratio Terhadap Capital Structure Pada Perusahaan Go Publik Di Bursa Efek Indonesia. Jurnal Bisnis STIE IBBI. ISSN 1858-3199. Medan. Medan: Sekolah Tinggi Ilmu Ekonomi IBBI.

Sudana, I. M. (2015). Teori \& Praktik Manajemen Keuangan Perusahaan. Jakarta: Penerbit Erlangga.

Wadati, L. W., \& Nafisah, S. (2017). Analisis Pengaruh Struktur Aset, Risiko Bisnis, Pajak Dan Likuiditas Terhadap Keputusan Pendanaan Pada Perusahaan Manufaktur Yang Terdaftar Di Bursa Efek Indonesia. Dinamika Akuntansi, Keuangan dan Perbankan (pp. 19-23). Semarang: Universitas Stikubank Semarang. 